\title{
Rashid Vatvat and Matlubon-kolle-taleb
}

\author{
Seyed Mohammad Bagher Kamaladdini \\ Department of Persian Literature and Language, Payam Noor University, Yazd, Iran \\ E-mail address: kamaladdini@pnu.ac.ir
}

\begin{abstract}
This article is based on an attempt to introduce and study a new-found manuscript containing four Hadith books: "Tohfa-al-seddigh, Fasl-al-khetab, Ons-al-lohfan, Matlubon-kolle-taleb." These four Hadith books include Hadiths of the first four caliphs, interpreted by Rashid- al-din Vatvat; distinguished writer of sixth century in Kharazmshahian court. The remarks of two hadith books (Faslal-khetab and Matlubon-kolle-taleb) are also changed into persion poem. With a thematic point of view, some scribes have collected these four Hadith books into one book and named it: " Remarks of the four Chosen fellows" or " Hundred remarks of the four prophets fellows". This manuscript is written in Naskh in the same style by Taher.
\end{abstract}

Keywords: Rashid Vatvat; Matlubon-kolle-taleb; manuscript

\section{INTRODUCTION}

No doubt to discover the literary style of each era, recognition of Fame poetry and prose of the period necessary. The Shnasayayy works that could contribute to the review and understanding of the language and literature of the period, precious.

Among the resources that have gone on Kharazmshahiyan is set to "Shahnshahnamh" by Mohammed Payizy (Lobabolalbab, Ufy, p. 345), "on Kharazmshahi" by Sayyid Sadr al-Din neyshaboori, "Msharb Altjarb" Ibn hazelnuts History of Khorezm from A. Khwarizmi, "Treatise Alasmyh" and the resale of Suhrawardi Shhfvr Neyshabouri noted. (Juwaynijahangosha history, Volume 2, Chapter I).

The remainder of the collection and presentation of cultural and literary giants of this period of history is necessary. His surviving works, including those who are distinguished in terms Kharazmshahiyan, is Rashid al-Din Vtvat. He was about thirty years, the Court has been willing Tsz Khwarazmshah much closer to him. We introduce and collect the scattered pieces serve little to the legacy will be written in Farsi.

This paper reviews and introduces VtvatNskhh-Ay line of Rashid al-Din. This version includes the mission "The gift of Abu Bakr Siddiq Alsdyq My Word", "word of Umar Ibn alKhattab my final word," "Anas Othman bin AffanAlhfan My Words" and "My Favorite WordGeneral Taleb Ali Ibn Abi Talib" is. This Rsalh-Ha-Chnankh caliphates of NvavynshanPydastcontains sayings that Vtvat by Rashid al-Din, a sixth-century literary ability in court Khwarazmshahs elaboration and addition, two letters of the words "final word" and "good total Talib "the Persian order of the string is pulled. 
The main objective of this paper is to introduce the features of Nskhh-Ay newfound form and content of the series is identified.

\section{ABOUT THE AUTHOR}

Sdalmlk Rashid al-Din Muhammad, son of Mohammed Abdul Jalil life that insight seems to eleven by the second caliph. Place Vladtsh Balkh and school military the same town as part of his studies with professor called Abvsdhrvy fulfilled after completing her education and become proficient in Persian and Arabic poetry Khwarizm go. (Literary History of Persia, Vol. 2, p 628).

Rashid Vtvat in early life he joined the government service Atsz Kharazmshahiyan time spent in court, where the attendant Sultan Sahebdivani Epistles and always has been . (lobabolAlalbab, Vol. 1, p 37).

Rashid's last name to "Vtvat" Her limbs were weak for the small size and because Vtvat name is Swallow bird species... (History of Literature, Vol. 2, p. 628).

Rashid al observed in Khorezm died in 573 AH. (Literary History of Persia, Vol. 2, p 628) (Lobabol Alalbab, part 19: p 29).

\section{ABOUT THE BOOK}

As noted above, this version includes the mission "The gift of Abu Bakr Siddiq Alsdyq My Words", "My final word word of Umar Ibn al-Khattab", "Anas Othman bin Affan Alhfan My Words" and "My Favorite Word-General Taleb Ali ibn Abi Talib" is. This Rsalh-Ha with hundreds of Hadith that each of the four caliphs as described by Vtvat Mqdmh-Hayy written on them.

1. Rashid al Vtvat in the introduction "I sought the good word of Ali Ibn Abi Taleb," The first hundred word essay has been described, writes: "I must see that it's a hundred - it was designated Jahez - in Arabic ir interpretation and the interpretation of each word in the last two verses of their facilities which is good, she is rigorous. "This paper makes some manuscripts including the present version of the Il-Arslan A. Mahmoud bin (M: 589) been submitted. (Ideal introduction to the Taliban, Vtvat).

2. In the preface, "the final word" hundred words preceding (Resale of the rebels desired) teaches and writes that "after a hundred word description Bsakht and the sum of the ranks because he was rescued and Bprdakht, Cobra religion and and the nation state and the great King", he requested that "Umar bin Al-Khattab final word in my name", he says he "gharar sayings and proverbs are rarely" seen obligation to pay, and he accepted the request to "to Jamil mentions synonyms and more Mtzaf Jzyl reward seeker's no room for error. article is not a bad person." (Introduction to the final word, Vtvat).

3. In the third preface notes that other "pillars of religion and state property objects and people," he insist that "the interest of other words nonsense" and Rashid exhorted his holy judgment, the treatise "Word of my Alsdyq Tohfat Abu Bakr Alsdyq "provides the" it's the Persian way of Brevity "is described. (Introduction Alsdyq gift, Vtvat).

4. In the preface to the last paper writes that she has asked the religious leaders as the word "Anas Othman bin Affan Allhfan My Word" as it also acquired and developed and wrote a short mustache. (Introduction ounces Allhfan, Vtvat). 
Rasheed two recent papers, "gifts Alsdyq" and "Intimacy Allhfan" has developed only a short description Persian, Arabic and verses and poems on them so as not Nyafzvdh.

\section{COPY CONTENT}

Remarks collected in four papers including ethical, spiritual, social, and self-knowledge that the article begins and ends this way:

1. Paper "gift Alsdyq" the first word begins with these words: "Industry Almrvf MT MsarAlsv'" (good deeds than bad fall, prevent) and the hundredth word ends with these words: Astghfr God and insoles to Myna and trust in God and insoles to Vkyla Ali.

2. Paper "final word" in the first word begins with these words: "Tfqhv ago Tsvdv '(Science teaching before they get married) and the hundredth word ends with the words: I do not Snth economy Phi PhiBdhijtihad ( moderation in St. leaps in innovation is better).

3. Resale "AnasAllhfan" the first word begins with these words: "It TrbhvaTajrva God" (the God of your business to make a profit) and the hundredth word ends with these words: "By Allah, Lee and Hoda and practice LkmBtah even Razi "(of God for themselves, and you, the right way and act in obedience he'd rather be satisfied).

4. Paper "Vtlvb the Taliban" in the first word begins with these words: "Le discovery Alghta' We certainly Azddt" (If you open the cover, Nyfzaym I am sure) and at the end of the hundred-word translation ends with this: "The heart Beyond AlahmqLsanh "(the fool after his tongue).

\section{MORPHOLOGICAL CHARACTERISTICS EDITION}

The paper: The current version of the positions identified therein, including all four of the dissertation is based on how the order is Tdvynshan. As Nsakh other way, this version is also on the Caliphs caliphates set. So that the article "Tohfat Alsdyq" (which is the sayings of Abu Bakr) and then "My final word word of Umar Ibn al-Khattab", then "Anas Othman bin AffanAllhfan My Word" and the "desirability of seeking My words of Ali Ibn Abi Talib "is written.

The introduction of Rashid al-Din Vtvat Rsalh-Ha scribe has written over them, and manipulating sentences Vtvat has to quote his own words.

First and last: so that the review essays suggests, this version does not have the first and last pages of "I and the end of the old book has fallen." The paper "Tohfat Alsdyq", introduction and part of 'al-Awwal the word "no. The description of the "First Word", begins with these words: "... psychotherapy. Than any Nk think about and ultimately end Nzrh "...

Finally, the paper "Overall good Taliban" in Middle Persian words ninety-ninth as this might result in withdrawal: "... it would be wise to speak argues, first in the hearts "...

Number of pages: 304 pages This version is generally 1 to 69 so that the page treatise "Thfhalsdyq" from page 70 to 157 monograph "final word" written.

Line layout: the entire book is written in naskh. Scribe the arts and their tastes, pages with red lining and black, border layout, then the Arabic, Persian and the number of words translated by the blonde, is different. To write a word, the number of words written in red and black colors with a bold statement to the Arabic hadith has abrogated. After the words 
"translate" the number of words written in red and the font size, and in the end, as the final words of the poem was written in black pen fine.

Introduction of paper with a small brush and black text but the word "Allah", "Mohammed" and the original Words (like "Ali" and "Overall good Taliban") in place of the text that is written in red An overview of the diagnosis booklet helps.

History Scribe and Scribe: In the paper "Tohfat Alsdyq" written: "... the time lunch was over on Saturday, the tenth of the month of Shawwal on Shryn duodenum and Tsmah Abdel line Alzyf, Makhdoom, Tahir Ata UllahBahad ... "and other similar Rsalh-Hay completion of 922 years of recorded history.

\section{ORTHOGRAPHY}

To learn more and better, some of the features of the writing of this manuscript Brmyshmrym:

1. "who" and "what" Mvsvlh with "and" non-verbal (the "who" and "what") and when connecting, without the "s" is written. Such as: Black, now, Jnank. The verb "is" connected to the word before writing. Like Mslst, that.

2. Some words such as "like" separate writing (a "like .("

3. To write the words in bearish mode, "or" not connected, the H (paced) uses. Like Tayfh', Srgshth', Drya' (instead of "Tayfh-Ay, Srgshth-Ay sea").

4. "to" after your connected all over the word without the "s" writes inarticulate. Like Bsvab, Bvyd, Bthdyd, Bamant, concrete, easily, so long, Bbhsht, Bykja.

5. Write "T" in Persian, with a "b" does not matter, both in single as well as writes the "stick" to.

6. Connect the pronoun disjunctive pronoun is sometimes used instead. Like her ordeal to him (instead of "Msybtsh on him").

7. "this" and "that" as "this" and "where" he writes .

8. "K" and "G" are both a rogue writes (in "K").

Whereabouts version of this manuscript is kept in the National Library of Kazakhstan in the "Catalogue of the Persian manuscripts in the National Library of Kazakhstan" has been recorded. (Kamaladdin, 2008: 74).

Other manuscripts from the collection "Four hundred word companion of the prophet ".

During the survey, it was observed that the Rsalh Hay Nskhh-Hayy of four separate in some Ktabkhanh-Hayy such as Istanbul, Ayasofya, turning offensive and available. But the details are perfect copies which consists of four treatises on the Shmrym:

1. Copy in the library Ayasofya a set number 2854 and called "The words of the four partner option" available. Contains four essays "ToḥfatAlsdyq", "final word", "AnasAllhfan" and "the good Taliban" is .katb that Maulvi Muhammad bin Ali, in the year Ramadan has written 896 copies it to the line. Image of Tehran University Central Library collection numbers 706 and 707 are pictures.

2. Another version of the library of the University of Istanbul and set to 407 and the number "four hundred word Nabi Sweetheart" is. Here are four letters were the same as the 
previous version. Name of the writer and not a history book, this version of the manuscript and nastaliq .kht .ksy from the collection number 524 in the Central Library of the Tehran University.

3. The collection of the library Atif Effendi to the number 2207 and consists of 6 letters are the first letters of "words of four alternative Sweetheart" is. None of the components, not the date and name of the scribe, and the latest date by the end of the sixth essay collection Heavens Dede Maulvi virtues that another cream - 928 Jomādā come to the show. Microfilm and photo copy numbers (367 and 732-731) are available at the Central Library of Tehran University.

\section{CONCLUSION}

Undoubtedly, introducing a line of rich cultural heritage of Persian Language and Literature-and-a valuable addition to preserving the works of the ancients, could be useful explorations of the history of scholarship and literary style interpretations.

This collection of essays "Four hundred words of the prophet companion" of Rashid alDin Vtvat (except paper "Overall good Taliban") has been wearing printed dresses and devotion are not supplied on the market. This version has features that can be corrected and printed in the collection is impressive.

\section{References}

[1] Vtvat historical significance of Rashid al-Din, KH Begay, H., Journal of Historical Research, University of Sistan and Baluchestan, Zahedan, 2009.

[2] Words a four-man selection, Vtvat, Muhammad Balkhi-life scribe, the manuscript number 2854, if the library Sofia, numbers 706 and 707 in the Central Library of Tehran University image.

[3] Pitch Alalbab, Vfy M., Edward J. Brown, with an introduction by Mohammad Ghazvini and new corrections and margins and suspension Saeed Nafisi, Hermes Publications.

[4] Facetiae Alamsal Trayf Alaqval, Vtvat, Rashid al-Din, correcting student Habiba, Tehran, legacy print publishing, 1997.

[5] Favored the rebels, Vtvat, Muhammad Balkhi-life markers, correction and suspension Mahmoud Abedi, printing, printers, Salman Farsi, Qom, 1986.

[6] Joint favorites ruby Hamawi, Hmvy Baghdadi, Shihab al-Din Abi Abdullah, translated by Mohammad ParvinGonabads, Tehran, Shiraz, 1983

[7] Literary History of Persia, fun, Zabihullah. Thirteenth Edition, Firdous Publications, Tehran, 1988.

[8] Join Jahangosha Juwayni, Juwayni, Bhaaldyn Ata Malek bin Muhammad bin Muhammad, Syed Shah Rukh Mousavis efforts on correcting Allama Muhammad Qazwini, hands Publications, Tehran, 2006.

[9] Hadaegh Alshr per minute extension, Vtvat, Rashid al-Din, the introduction of a correction Abbas Eqbal Ashtiani, Tehran senate and Tahoori, 1983. 
[10] Poems, Vtvat, Rashid al-Din, and deal with the introduction and correct Saeed Nafisi, bookstore Rain, Shah Abad, 1960.

[11] Books of poetry, innate, Abdul Alvas, Volume 2, Edited by Zabihullah Safa, Tehran University Press, Tehran.

[12] Spoken and eloquent, Forozanfar Badi'ozaman, Third Edition, BS Publications, Tehran, 1979.

[13] List of Persian manuscripts in the National Library of Kazakhstan, Kamal al-Din, SMB, dikes Press Releases, Almaty, 2008 in 1962. 